\title{
Hybrid System Using Two Panel Parallel Solar Cells 110 WP and PLN Power Source
}

\author{
Sarono Widodo ${ }^{1}$, Agus Rochadi ${ }^{2}$, Muhammad Anif ${ }^{3}$ \\ ${ }^{1}$ Electrical Engineering Department, Politeknik Negeri Semarang
}

\begin{abstract}
The limited availability of electricity and its continued use need to was sought for savings by providing alternative energy. New renewable energy sourced from sunlight can be an energy solution for electrical energy needs. Savings can be done using hybrid techniques from two sources to supply the load. This research makes hybrid plants utilizing sunlight using two panels of $110 \mathrm{wp}$ capacity solar cells installed parallel to get a large output current. In this hybrid system used a deep cycle 12v / 100 Ah battery to supply 100-250 watts of light for three to four hours. The test results show that battery charging is very dependent on solar radiation and is needed for seven hours to reach $88 \%$ capacity and the inverter supplies a load of 213.5 watts on average for 45 minutes requiring $20 \%$ of battery capacity.
\end{abstract}

Index Terms- Hybrid,inverters, electricity,solar cells.

\section{PRELIMINARY}

Energy produced from sunlight has become an alternative source of electrical power and can even be the primary energy source for electricity needs. Solar radiation that hits the surface of photovoltaic (PV) solar panels turns into electricity.

The technology of photovoltaic solar cells, as shown in Figure 1, consists of two positively and negatively charged semiconductor layers. When the sun illuminates the semiconductor, there will be an electron displacement, and the electric current will produce a DC [1], [2].

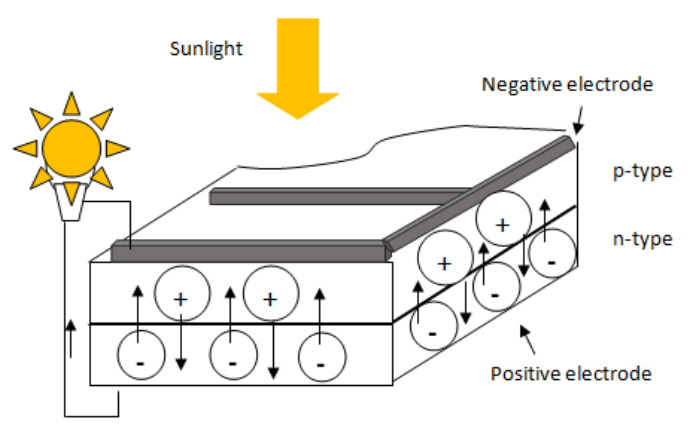

Fig.1.The working principle of photovoltaic

Electrical energy generated from sunlight can be fully used to supply loads according to the capacity of solar cell panels, inverters, and batteries used in solar power generation systems. In specific needs, a hybrid technique is needed to supply loads from two different electrical energy sources. Hybrid systems combine two sources of electrical energy using a one-way source (generator) method to provide the load. This system regulates one of the two sources working to supply the load. When the solar cell supplies to the load, the PLN power source will automatically be cut off. When the inverter is no longer able to provide electricity, the controller automatically transfers it to the PLN power source. [3], [4]. Hybrid systems are intended to deal with the problem of electricity supply deficits from one source to another so that the electricity supply is maintained [5].

\section{DEVELOPMENT OF HYBRID SYSTEMS}

Hybrid systems are made to meet the energy supply to loads, especially parking lighting, which is turned on at night for three to four hours. During the day there is no load to be supplied, and entirely the electrical energy produced by sunlight through PV will be controlled by the Battery Charger Regulator to charge the battery. Switching controller will detect if the battery charging process is in progress and at the same time the load is activated; then the load supply is carried out by an electric source. When charging the battery reaches the range of $90 \%$, the inverter that converts dc voltage from the battery to 220 volts $\mathrm{AC}$ will be activated to supply the load, and the controller will stop the electricity supply.

The construction of a hybrid system is used as an energy source to supply light loads in the parking area. Figure 2 shows the design of hybrid energy. From the calculation of solar cells and batteries used [6], two solar units with a parallel capacity of $110 \mathrm{Wp}$ are needed, a 12V / $100 \mathrm{Ah}$ deep cycle battery, a Mesonic MF1500 model inventer.

The specifications of the solar cell panel in the design made are:

Peak power: 110 watts 
Open circuit voltage: 21.9 volts

Short circuit current: 6.40 amperes

Peak voltage: 18.5 volts

Peak current: 5.95 amperes

Test condition, the intensity of the sun is $1000 \mathrm{~W} / \mathrm{m} 2$

Temperature: $25^{\circ} \mathrm{C}$

PV modules are the results of tests by manufacturers on standard test conditions with solar radiation of $1000 \mathrm{~W} /$ $\mathrm{m} 2$ and at cell temperature $250 \mathrm{C}$, and these results can change under different climatic operating conditions [7].

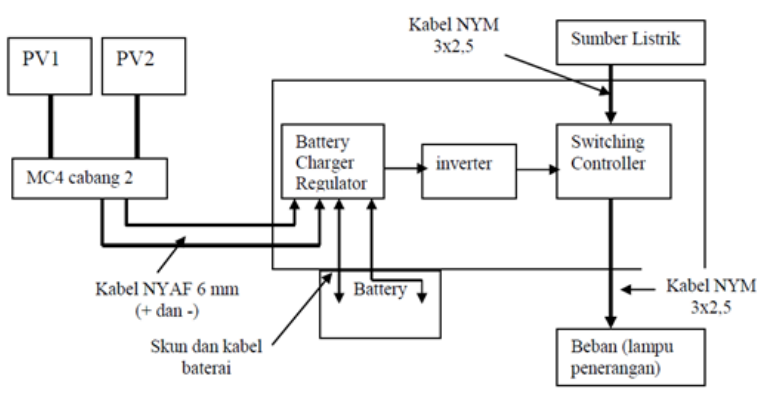

Fig.2. Development of a hybrid system

\section{RESULTS AND ANALYSIS}

The hybrid system installation uses $6 \mathrm{~mm}$ NYAF type wiring to connect two units of hybrid solar cell panels. Two solar cell panels are connected in parallel using a pair of MC4 connector two branches and a pair of MC4 connector one branch. To connect to the load and power source from a hybrid device used NYM 3x2,5 cable.

\subsection{Installing a hybrid system}

Hybrid system installations include solar cell panel installation, installation of solar cell panels and batteries to hybrid devices and installation of hybrid devices to loads and electricity sources. Figure 3 shows the installation of parallel solar cell panels to produce large currents according to the $100 \mathrm{Ah}$ battery requirement.

Figure 4 shows the installation of solar cell panels and batteries to hybrid devices. The solar cell panel is connected to the input of a hybrid device with polarity (+) and (-) according to the panel connector using NYAF cable. Battery 12 volt / $100 \mathrm{Ah}$ battery terminal connected to the $(+)$ and (-) in the hybrid device.

At the end of the installation is carried out from the hybrid device to the load and from the power source as shown in figure 5.

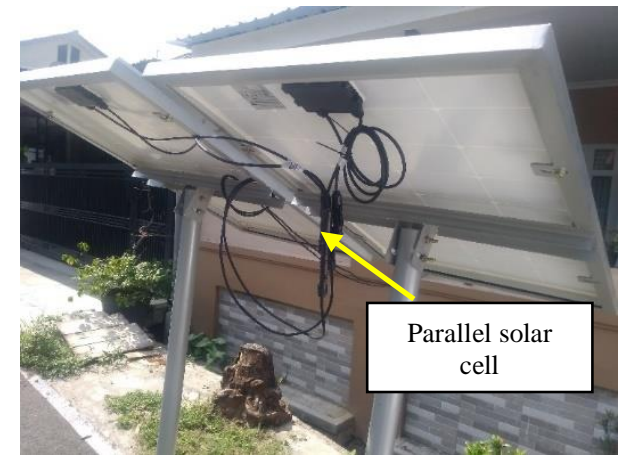

Fig.3. Installing solar cell panels

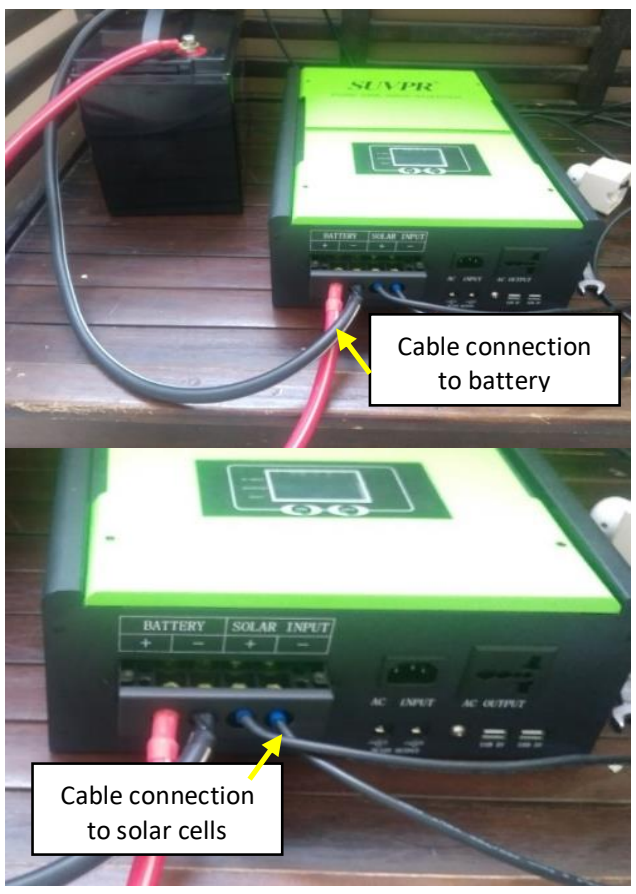

Fig.4. Installing batteries and solar cell panels into hybrid devices
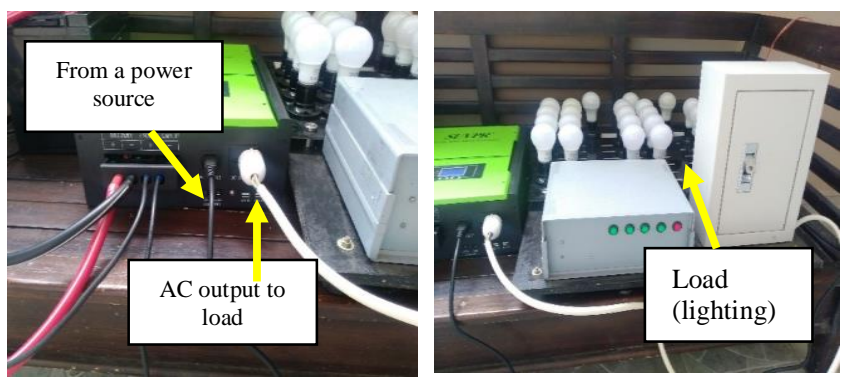

Fig.5. Installing a hybrid system into a load 


\subsection{Results}

Testing of hybrid systems includes testing solar cell panel output, testing battery charging and testing the load supply by inverter output.

\subsection{Testing the voltage and current of solar cell output}

To measure the current and output voltage of a solar cell requires three measuring devices, namely two measuring devices in the form of a voltage gauge and a measuring instrument to measure electric current. Three measuring devices use two-volt meters of digital and oneampere meter digital. The flow produced by solar panels is quite high, not less than 8 amperes, it requires an ampere meter with an ampere meter measurement range of up to 15 A DC. The measuring instrument used is the type CD772 as a current measuring device on solar panels and two voltmeter types CD800a for measuring solar panel voltage and battery voltage. Figure 6 shows the voltage measurements generated from solar cells and batteries.
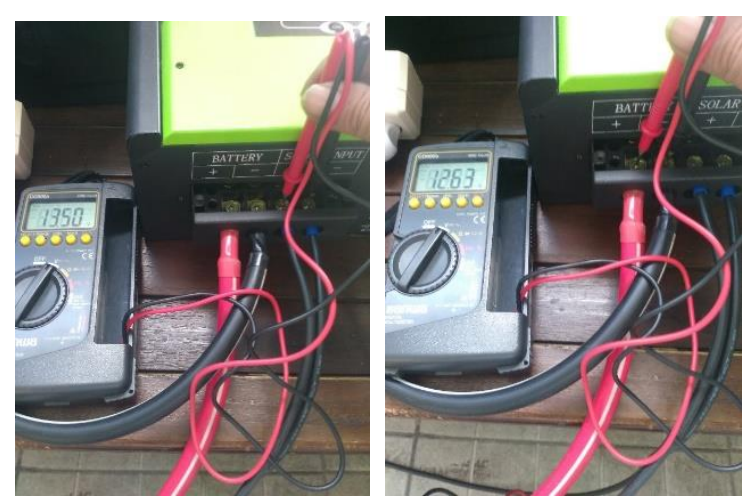

Fig.6. Measurement of the solar cell and battery voltage

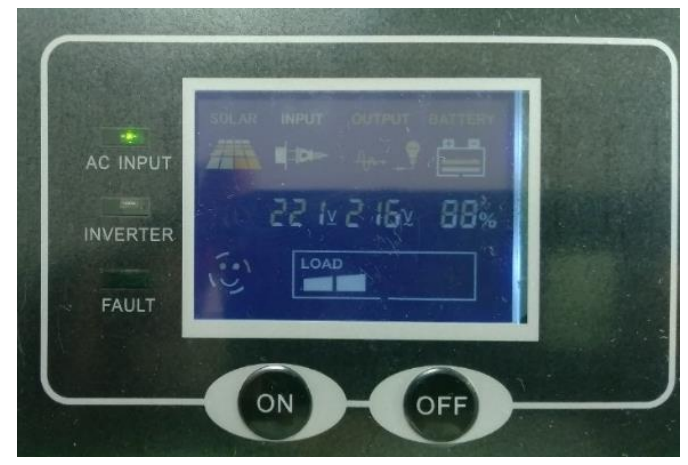

Fig.7. Battery charging indicator from solar cells
Figure 7 shows the process of charging the battery from a solar cell. It appears on the indicator that during the battery charging process, PLN electricity fully supplies the load, so the input AC indicator lights up. This test is carried out during the day, and the lights are turned on.

The test results as in table 1 show that battery charging reaches $88 \%$ for seven hours. Battery charging time depends entirely on solar radiation on solar cells. In this test, after seven hours the charging current generated from the cell solar continued to shrink so that the battery charging became sluggish and stopped at around $88 \%$.

Table 1

Voltage and current generated by solar cells and charging batteries

\begin{tabular}{|c|c|c|c|c|c|}
\hline Time & $\begin{array}{l}\text { Cell solar } \\
\text { voltage } \\
\text { output } \\
\text { (V) }\end{array}$ & $\begin{array}{l}\text { Cell } \\
\text { solar } \\
\text { current } \\
\text { output } \\
\text { (A) }\end{array}$ & $\begin{array}{l}\text { Battery } \\
\text { voltage } \\
\text { (V) }\end{array}$ & $\begin{array}{c}\text { Surface } \\
\text { temperature } \\
\text { of solar } \\
\text { cells }\left({ }^{\circ} \mathrm{C}\right)\end{array}$ & $\begin{array}{c}\text { Battery } \\
\text { charging }(\%)\end{array}$ \\
\hline 09.00 & 13,05 & 2,3 & 12,6 & 39,3 & 20 \\
\hline 09.30 & 13,3 & 3,5 & 12,68 & 42,2 & 24 \\
\hline 10.00 & 13,4 & 3,9 & 12,71 & 44,4 & 29 \\
\hline 10.30 & 13,4 & 4,1 & 12,73 & 44,1 & 32 \\
\hline 11.00 & 13,5 & 5,6 & 12,87 & 49,5 & 38 \\
\hline 11.30 & 13,85 & 6,67 & 12,74 & 56,2 & 45 \\
\hline 12.00 & 13,98 & 6,7 & 12,78 & 56,7 & 48 \\
\hline 12.30 & 14,11 & 7,04 & 12,82 & 59,4 & 59 \\
\hline 13.00 & 13.81 & 6,5 & 12,65 & 55,3 & 66 \\
\hline 13.30 & 13,92 & 6,7 & 12,78 & 57,1 & 74 \\
\hline 14.00 & 13,8 & 5,1 & 12,74 & 53,2 & 78 \\
\hline 14.30 & 13,72 & 4,3 & 12,67 & 47,4 & 83 \\
\hline 15.00 & 13,35 & 2,7 & 12,23 & 43,2 & 87 \\
\hline 15.30 & 13,21 & 1,5 & 12,18 & 40,8 & 88 \\
\hline 16.00 & 13,11 & 1,2 & 12,05 & 37,5 & 88 \\
\hline
\end{tabular}

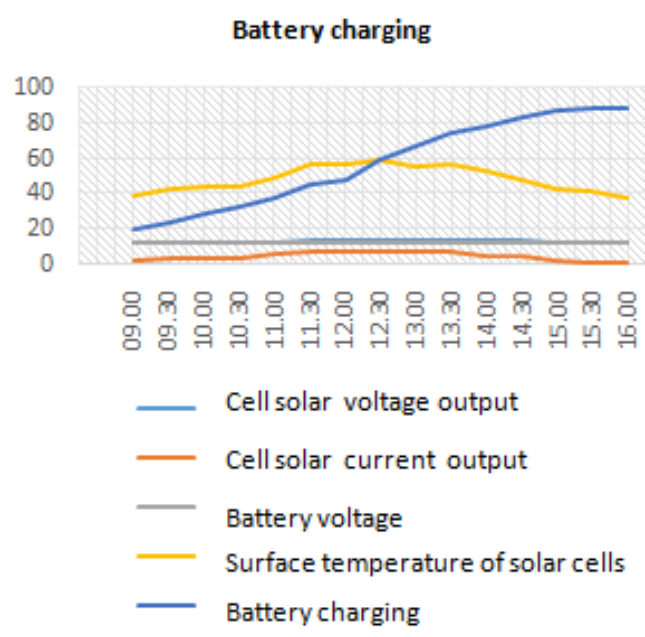

Fig.8. Charging batteries from solar cells 
Figure 8 shows that solar cells charge the battery, and charging continues to increase with changes in current and voltage. Charging the battery becomes weaker along with the reduced flow generated from solar cells, this is due to the feeble beam of sunlight that falls on the surface of the solar cell. Charging continues to weaken until the current generated in the range of below 1.2 amperes with an indicator of $88 \%$ and then tiny once approach does not have a significant effect.

\subsubsection{The inverter test supplies the load}

The inverter will convert the dc source from the battery to the output of a 220-volt ac voltage that is used to supply a load (lighting) with 220 -volt ac voltage. When the inverter works, the switching controller will disconnect the power source. Thus all the energy used to supply the load is all charged or provided by the inverter output (ac output). Figure 9 shows the load testing simulation board.
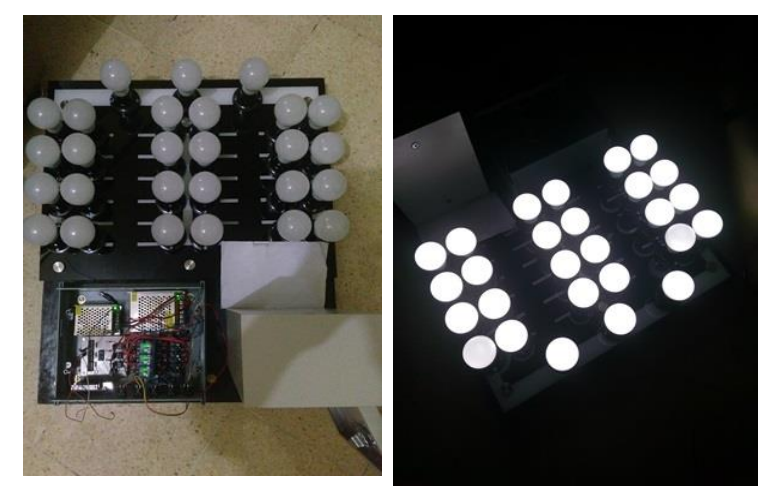

Fig.9. The load testing simulation board

Table 2 represents the measurement results of inverter output when supplying the load as shown in table 2 . In this test, the hybrid device connects the output of the solar cell and, the input power source and the total lamp power is 213.5 watts. The output of the inverter supplies lights for three hours with a decrease in the average battery capacity of $12-15 \%$ every thirty minutes or about $4 \%$ every ten minutes of use of the supply to the load. When the inverter works, the switching controller disconnects the power source so that the inverter is in charge of supplying all the lights. In the range of $22 \%$ of the battery capacity, the switching controller moves (disconnects) the supply flow from the inverter to the electricity source 220 from the PLN.

Figure 10 represents the inverter when supplying a load of 213.5 watts for three hours and figure 11 shows load testing activities. The inverter delivers about $20 \%$ of electricity capacity for 45 minutes. In the range of $20-22 \%$ battery capacity, the controller disconnects the supply from the inverter and switches it to a power source. The implementation of this test is carried out during the day; therefore after the controller diverts to the power source, the solar cell automatically fills up.
Table 2

Output inverter-battery capacity

Load 213,5 watt

\begin{tabular}{cc}
\hline Test and measurement time & Battery percentage (\%) \\
\hline 10.00 & 100 \\
10.30 & 88 \\
11.00 & 75 \\
11.30 & 64 \\
12.00 & 52 \\
12.30 & 39 \\
13.00 & 22
\end{tabular}

Switch to a power source

Tests for battery charging without load during 7.5 hours of irradiation obtained by the range of $60 \%$ in conditions of solar radiation received by solar cell panels vary (sometimes cloudy and sunny) as shown in figure 12 . When solar radiation is high which is characterized by high surface temperatures then the current and the voltage generated from solar cell panels is very large, on the contrary, if solar radiation is relatively low, then the power produced by solar cell panels is also small. As long as the current supplied to the battery is large the charging is very fast as indicated by the percentage of battery charging, otherwise charging becomes slow.

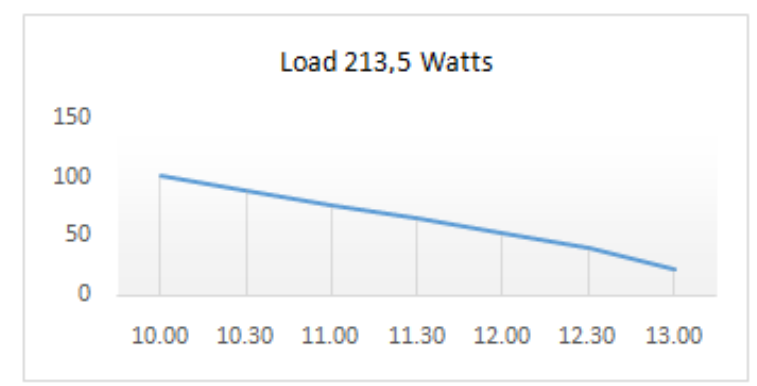

Fig.10. The inverter supplies 213.5 watts of load

Electrical energy produced by solar cell panels is stored in the battery and converted to 220 volt AC power using an inverter device. The duration of the inverter supplying the load depends on the load power. In testing the 245 watts power lamp as in figure 13, the inverter can provide for 45 minutes for a battery capacity of $20 \%$, while to supply a load of 101.5 watts it can supply for 52 minutes with a battery capacity of $16 \%$ as shown in Figure 14. 


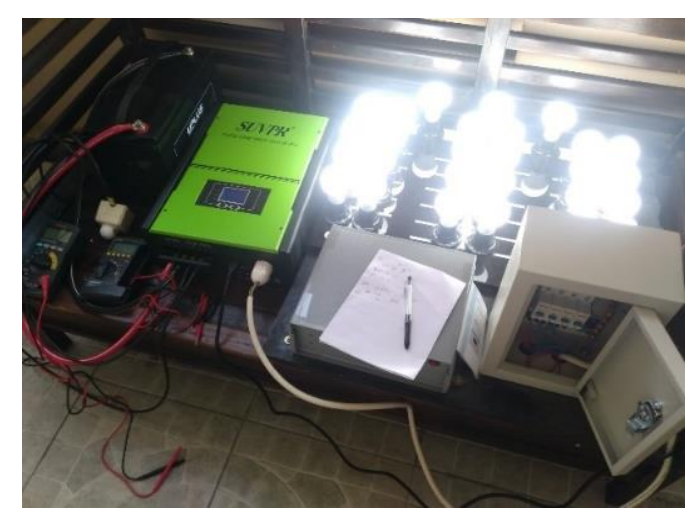

Fig.11. Load testing

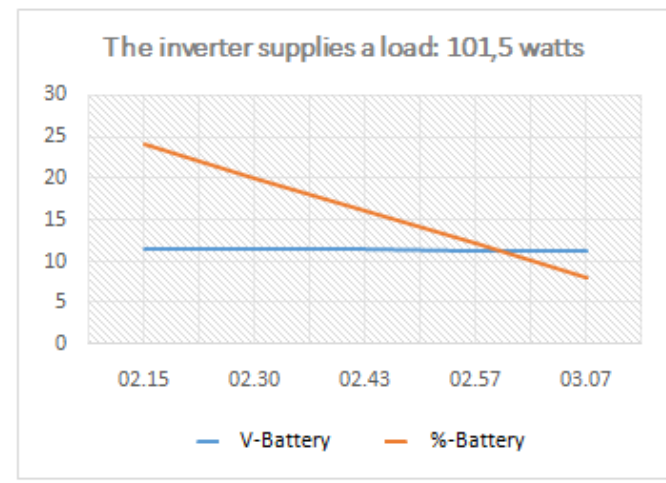

Fig.14. The inverter supplies 101.5 watts of load

At a load of 245 watts, the average battery usage is to supply capacity of $1 \%$ every 2 minutes. If the average battery capacity of charge is $80 \%$ optimal, it can ready for use 160 minutes or 1.5 hours. Whereas at a load of 101.5 watts the inverter supplies a capacity of about three minutes more every $1 \%$. So that for an optimal battery of $80 \%$ it will be able to support for no less than 4 hours. Thus this design can be implemented in the parking area lighting requirements that use lamp loads for 100 watts up to 250 watts with a duration of time that can be supplied by an inverter 1.5 hours to 4 hours.

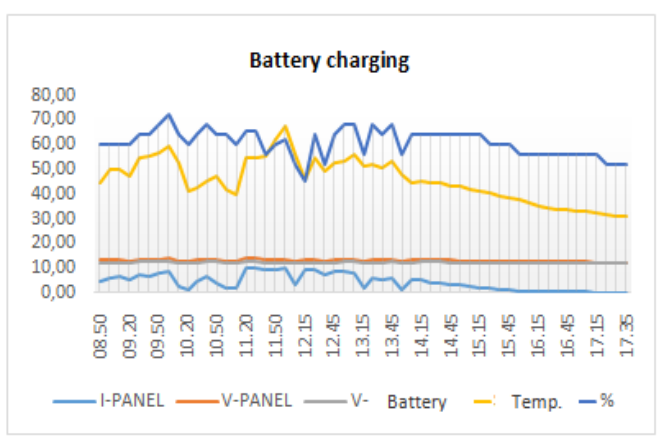

Fig.12. Charge battery without the load

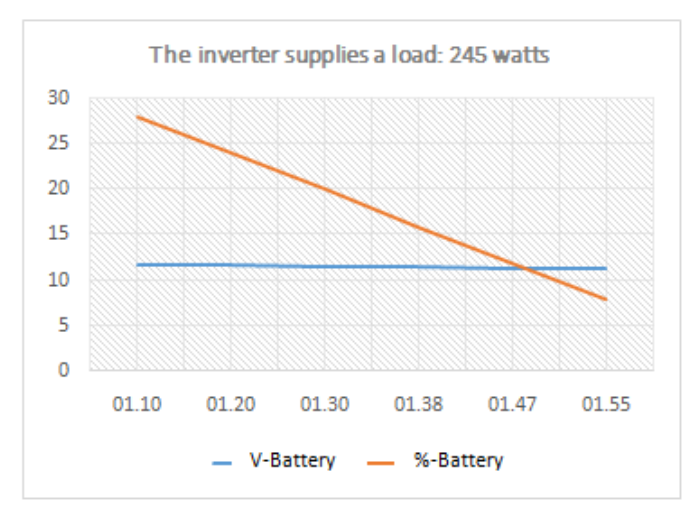

Fig.13. The inverter supplies 245 watts of load

\section{CONCLUSION}

The results of testing and analysis can be summarized as follows:

1. Hybrid systems can work to supply lighting models for parking areas.

2. Solar radiation significantly affects the capacity of battery charging by solar cell panels.

3. Charging a 12 volt / 100 Ah battery takes seven hours for a maximum charge of $88 \%$.

4. Parking area lighting that uses a lamp load of 100 watts to 250 watts can be supplied by the inverter 1.5 hours to 4 hours.

\section{References}

[1] Andi Julisman,Ira Devi Sara,Ramdhan Halid Siregar (2017). Prototipe Pemanfaatan Panel Surya Sebagai Sumber Energi Pada Sistem Otomasi Atap Stadion Bola. KITEKTRO:Jurnal Online Teknik Elektro Vol.2, No.1, 2017,e-ISSN:2252-7036,35-42.

[2] Junial Heri (2012). Pengujian Sistem Pembangkit Listrik Tenaga Surya Solar Cell Kapasitas 50 WP. ENGINEERING: Vol.4, No.1, 2012,47-55.

[3] Hasyim A.,Jatmiko,Angga (2012).Simposium Nasional RAPI XI FT UMS : Intensitas Cahaya Matahari Terhadap Daya Keluaran Panel Sel Surya.

[4] Liem Ek Bien,Ishak Kasim,Wahyu Wibowo (2008). Perancangan Sistem Hibrid Pembangkit Listrik Tenaga Surya dengan Jala-jala Listrik PLN untuk Rumah Perkotaan. JETri. Vol.8,No.1,Agsutus 2008,37-56.

[5] Mahmud Abdul M.B.,Anik Deb,Arefin Nasir (2013).Optimum Planning of Hybrid Energy System using HOMER for Rural Electrification.International Journal of Computer Applications. Vol.66,No.13,2013,45-52.

[6] Sarono Widodo,Agus Rochadi,Muhammad Anif (2018). Desain Energi Hibrida Solar Panel dan Listrik untuk Penerangan Area Parkir. Seminar Nasional Terapan Riset Inovatif (SENTRINOV). 
[7] Abdul R.J,Saleem R.S,Abdul Q.J.(2018) Influence of Temperature on Electrical Characteristics of Different Photovoltaic Module Technologies. Int.Journal of Renewable Energy Development (IJRED) 7 (2),2018,85-91. 